\title{
IMPLEMENTASI MANAJEMEN PENERIMAAN PESERTA DIDIK BARU BERBASIS ONLINE DI SMK NEGERI 6 MAKASSAR
}

\author{
Nurdian Ramadhani Ansar, Ratmawati T, Andi Wahed \\ Universitas Negeri Makassar \\ E-mail: Dianramadhanii33@gmail.com
}

\begin{abstract}
Abstrak: Fokus penelitian ini ialah mengungkap implementasi Manajemen Penerimaan Peserta didik baru berbasis Online di SMK Negeri 6 Makassar melalui penerapan sistem PPDB Online. Penelitian ini menggunakan pendekatan kualitatif yang dimaksudkan untuk mendapatkan pemahaman yang lebih luas dan mendalam terhadap data yang ditemukan dan dihadapi peneliti. Hasil penelitian menunjukkan bahwa:dalam penentuan daya tampung calon peserta didik baru di SMK Negeri 6 Makassar, ditentukan atas beberapa pertimbangan yaitu diantaranya melihat dari jumlah Guru yang tersedia serta sarana dan prasarana yang ada di SMK Negeri 6 Makassar. Kebijakan pada sekolah yaitu mengikuti petunjuk teknis dari Provinsi sebagai acuan dalam pelaksanaan PPDB Online di SMK Negeri 6 Makassar adapun penetapan tempat untuk Pelaksanaan PPDB online di tetapkan di ruangan rapat guru yang menjadi pilihan bagi panitia penyelenggara PPDB Online dan anggaran pada PPDB Online yaitu berasal dari Dana BOS Sekolah itu sendiri pada sistem Penerimaan PPDB Online tahun ajaran 2018/2019, menerapkan 4 jalur yaitu jalur afirmasi, prestasi, khusus dan akademik Penyeleksian pada PPDB Online saat ini telah terhubung langsung dengan database Dinas Sosial dan Dinas Pendidkan, Kemenag dan KONI hal ini menghindari kecurangan pada pelaksanaan PPDB Online. Prosedur penerimaan peserta didik baru yaitu PPDB online saat ini lebih transparansi dan memudahan bagi peserta didik serta panitia dalam menverifikasi data yang sebenarnya, serta pertanggung jawaban panitia lebih mudah dikarenakan semua data telah menggunakan sistem.
\end{abstract}

Kata kunci: Manajemen Peserta didik, Penerimaan Peserta didik, Online.

\begin{abstract}
The focus of this study is to uncover the implementation of new Online-based Student Admissions Management at SMK Negeri 6 Makassar through the application of the PPDB Online system. This study uses a qualitative approach that is intended to gain a broader and deeper understanding of the data found and faced by researchers. The results showed that: in determining the capacity of prospective new students at Makassar State Vocational High School 6, it was determined by several considerations which included looking at the number of teachers available as well as existing facilities and infrastructure at Makassar State Vocational High School 6. The policy on the school is to follow the technical instructions from the Province as a reference in the implementation of PPDB Online at Makassar State Vocational High School 6 as well as the determination of places for PPDB online in the teacher meeting room which is the choice for the PPDB Online organizing committee and the budget for PPDB Online from Dana BOS School itself In the PPDB Online Acceptance system for the 2018/2019 school year, applying 4 paths namely affirmation, achievement, special and academic paths Selection in PPDB Online is now directly connected to the database of the Social Service and Education Office, Ministry of Religion and $\mathrm{KONI}$ this avoids cheating on the implementation of PPDB Online. The new student admission procedure, PPDB online is now more transparent and makes it easier for students and organizers to verify the actual data, and committee accountability is easier because all data has been by system.
\end{abstract}

Key words: Management of Students, Acceptance of Students, Online.

Peningkatan mutu pendidikan di sekolah perlu di dukung oleh perencanaan yang baik, perencanaan dan pelaksanaan manajemen peserta didik mempunyai wilayah jangkauan mulai dari saat akan mengadakan penerimaan peserta didik baru sampai dengan pelulusannya. Perkembangan teknologi informasi saat ini menimbulkan dampak yang sangat kuat terhadap kompleksitas manajemen pada umumnya, khususnya manajemen pendidikan. di samping itu, teknologi informasi semakin di butuhkan oleh lembaga pendidikan khususnya dalam meningkatkan kelancaran aliran informasi dalam lembaga pendidikan, kontrol kualitas, dan menciptakan aliansi dengan pihak lain yang dapat meningkatkan nilai lembaga pendidikan tersebut.

Menurut (Gunawan, 2017) mengatakan bahwa "PPDB adalah kegiatan penerimaan 
dan seleksi calon peserta didik pada suatu sekolah. Seleksi ini berkaitan dengan kemampuan akademik dan bakat minat terhadap jenjang pendidikan ke arah tujuan yang di inginkan. (Sholihin \& Mujilahwati, 2014) Penerimaan Peserta Didik Baru merupakan proses seleksi akademis calon siswa untuk menuju jenjang pendidikan yang lebih tinggi. PPDB dengan segala sistemnya, dilakukan untuk mengetahui dan mengukur input sekolah guna membantu perkembangan sekolah serta diharapkan dapat memberikan kontribusi yang tinggi dalam merencanakan dan melaksanakan kegiatan pendidikan dan pembelajaran di masa yang akan datang." Penerimaan Peserta Didik Baru yang familiar dengan akronim PPDB adalah kegiatan rutin tahunan yang merupakan tahap seleksi bagi calon peserta didik baru yang diselenggarakan oleh panitia tingkat Sekolah dibawah pengawasan dan koordinasi Dinas Pendidikan (Purwanti, Irawati, Adiwisastra, \& Bekti, 2019)

PPDB online adalah sebuah sistem yang dirancang untuk melakukan seleksi secara otomatis mulai dari proses pendaftaran, seleksi hingga pengumuman seleksi yang dilakukan secara online.(Sari, 2016)

Berdasarkan Peraturan Manteri Pendidikan Dan Kebudayaan Republik Indonesia Nomor 14 Tahun 2018 Tentang Penerimaan Peserta Didik Baru Pada Taman Kanak-Kanak, Sekolah Dasar, Sekolah Menengah Pertama, Sekolah Menengah Atas, Sekolah Menengah Kejuruan, Atau Bentuk Lain Yang Sederajat Pasal 4 ayat 3: "Pelaksanaan diutamakan menggunakan mekanisme dalam jaringan (daring)."

Menurut (Mulyasa, 2004) mengatakan bahwa "Manajemen Peserta Didik adalah penataan dan pengaturan terhadap kegiatan yang berkaitan dengan peserta didik, mulai masuk sampai keluarnya peserta didik tersebut dari suatu sekolah. Manajemen kesiswaan bukan hanya berbentuk pencatatan data peserta didik, melainkan meliputi aspek yang luas yang secara operasional dapat membantu upaya pertumbuhan dan perkembangan peserta didik melalui proses pendidikan di sekolah."

(Mulyasa, 2004) mengartikan

Manajemen Peserta didik bertujuan untuk mengatur berbagai kegiatan dalam bidang peserta didik agar kegiatan pembelajaran di sekolah dapat berjalan lancar, tertib, dan teratur, serta mencapai tujuan pendidikan sekolah. Untuk mewujudkan tujuan tersebut, bidang manajemen peserta didik sedikitnya memiliki tiga tugas utama yang harus diperhatikan, yaitu penerimaan murid baru, kegiatan kemajuan belajar, serta bimbingan dan disiplin.

\section{Analisis penerimaan peserta didik baru}

Sebelum melakukan aktivitas penerimaan peserta didik baru, pada masing-masing jenjang pendidikan formal terlebih dahulu melakukan analisis kebutuhan peserta didik. Dalam melakukan proses analisis, bagian yang menjadi pertimbangan utama adalah daya tampung kelas atau jumlah kelas yang tersedia, dalam arti bahwa rasio tenaga pengajar dengan peserta didik dalam satu kelas dapat seimbang sesuai dengan kebijakan yang berlaku.

(Kompri, 2015) memberi keterangan bahwa, yang termasuk dalam kegiatan analisis penerimaan peserta didik baru adalah merencanakan jumlah siswa yang akan diterima yaitu daya tampung sekolah dan kelas, rasio peserta didik dan guru yang bertujuan membandingkan antara banyaknya peserta didik dan guru dapat seimbang dan menyusun program kegiatan peserta didik, meliputi visi misi dan tujuan sekolah, minat bakat peserta didik, sarana dan prasarana, anggaran yang tersedia dan tenaga kependidikan yang tersedia.

\section{Kebijakan penerimaan peserta didik baru}

(Prihatin, 2011) mengemukakan bahwa "Kebijakan penerimaan peserta didik yaitu berhubungan dengan penggunaan dasardasar manajemen peserta didik agar seseorang di terima sebagai peserta didik di suatu sekolah, calon peserta didik haruslah memenuhi persyaratan-persyaratan sebagaimana yang telah ditentukan. Kebijakan operasional penerimaan peserta didik baru, memuat aturan mengenai jumlah peserta didik yang dapat di terima di suatu sekolah. (Mutiarin \& Wijaya, 2017) Penentuan mengenai jumlah peserta didik, tentu juga di dasarkan atas kenyataankenyataan yang ada di sekolah (faktor kodisional sekolah). Faktor kondisional tersebut meliputi: daya tampung kelas baru, kriteria mengenai peserta didik yang dapat diterima, anggaran yang tersedia, prasarana dan sarana yang ada, tenaga kependidikan 
yang tersedia, jumlah peserta didik yang tinggal di kelas satu, dan sebagainya."

\section{Sistem penerimaan peserta didik baru}

Sistem penerimaan peserta didik baru adalah mekanisme cara penerimaan peserta didik baru (Latri, 2017). Ada dua macam sistem penerimaan peserta didik baru. Pertama, dengan menggunakan sistem promosi, sedangkan yang kedua dengan menggunakan sistem seleksi. Yang di maksud dengan sistem promosi adalah penerimaan peserta didik baru, yang sebelumnya tanpa menggunakan seleksi. (Sularto, Wahyudi, \& Sukmawati, 2018) Mereka yang mendaftar sebagai calon peserta didik di suatu sekolah, di terima semua begitu saja. Sehingga mereka yang mendaftar menjadi calon peserta didik, tidak ada yang di tolak. Sistem promosi demikian, secara umum berlaku pada sekolah-sekolah yang pendaftarannya kurang dari jatah atau daya tampung yang di tentukan. Kedua, adalah sistem seleksi. Sistem seleksi ini dapat di golongkan menjadi tiga macam. Pertama, seleksi berdasarkan daftar nilai ujian akhir nasional (UAN), yang kedua berdasarkan penelusuran minat dan kemampuan (PMDK), sedangkan yang ketiga berdasarkan tes masuk.

(Syafi, Eka, Sari, \& Arif, 2018) Dengan manfaat dan kemudahan teknologi yang sudah ada, sudah seharusnya pengembangan sistem informasi penerimaan siswa baru (PSB) ini dikembangkan oleh tiap-tiap sekolah.

\section{Kriteria penerimaan peserta didik baru}

Menurut (Prihatin, 2011) yang dimaksud dengan kriteria adalah patokan-patokan yang menyatukan bisa atau tidaknya seorang untuk diterima sebagai peserta didik. Ada tiga macam kriteria penerimaan perserta didik. Pertama, adalah kriteria acuan patokan (standard criterian referenced), yaitu suatu penerimaan peserta yang didasakan atas patokan. Patokan yang telah ditentukan sebelumnya. Dalam hal ini, sekolah terlebih dahulu membuat patokan bagi calon peserta didik dengan kemampuan minimal setingkat dengan sekolah yang menerima peserta didik. Sebagai konsekuensi dari penerimaan yang didasarkan atas kriteria, jika semua calon peserta didik yang mengikuti seleksi memenuhi patokan minimal yang ditentukan maka mereka harus diterima semua. Sebaliknya, jika calon peserta didik yang mendaftar kurang memenuhi patokan minimal yang telah ditentukan, peserta didik akan ditolak atau tidak diterima.

\section{Prosedur penerimaan peserta didik baru}

Menurut Imron (2011) adapun prosedur penerimaan peserta didik baru adalah pembentukan panitia penerimaan peserta didik baru, rapat penentuan peserta didik baru, pembuatan, pemasangan atau pengiriman pengumuman, pendaftaran peserta didik baru, seleksi, penentuan peserta didik baru yang diterima, pengumuman peserta didik yang diterima dan registrasi peserta didik yang diterima dan registrasi peserta didik yang diterima.

\section{METODE}

Penelitian ini menggunakan pendekatan kualitatif yang dimaksudkan untuk mendapatkan pemahaman yang lebih luas dan mendalam terhadap data yang ditemukan (Moleong, 2014). .Alasan penelitian ini menggunakan pendekatan kualitatif karena penelitian ini tidak berkenaan dengan angka-angka, tetapi mendeskripsikan secara jelas dan terperinci serta secara empiris memperoleh data yang mendalam dari fokus penelitian.

Dalam penelitian ini, peneliti bertindak sebagai pengumpul data dan sebagai instrumen aktif dalam upaya mengumpulkan data dilapangan, sedangkan instrumen pengumpulan data yang lain selain manusia adalah berbagai bentuk pengumpulan data berupa pedoman wawancara, pedoman observasi, dan pedoman dokumentasi yang dapat digunakan untuk menunjang proses pengumpulan data dari penelitian.

Pada penelitian ini, peneliti melakukan pengumpulan data dengan melakukan wawancara kepada informan seperti Kepala Sekolah, Wakil Kepala Sekolah, bagian Kesiswaan, dan Operator Sekolah. Selain itu peneliti melakukan observasi dengan mengamati terkait dengan implementasi penerimaan peserta didik berbasis online.

Lokasi tempat Penelitian terletak di Jl. Andi Djemma No. 132, Banta-bantaeng, Kecamatan Rappocini, Kota Makassar, Provinsi Sulawesi Selatan.

Untuk memperoleh data atau informasi yang dibutuhkan dalam menjawab permasalahan yang dikaji dalam penelitian, 
maka diperlukan adanya subjek atau informan penelitian. Dalam penelitian ini, subjek penelitiaannya adalah kepala SMK Negeri 6 Makassar, wakil kepala SMK Negeri 6 Makassar bagian Kesiswaan, dan admin/operator sekolah sebagai informan kunci.

Teknik pengumpulan data, yaitu wawancara, Dokumentasi dan Observasi.

Analisis data merupakan kegiatan setelah data dari seluruh responden atau sumber data yang lainnya terkumpul. Setelah semua data terkumpul, maka langkah selanjutnya yang dilakukan oleh peneliti yaitu mengolah data atau bisa disebut analisis data. (Sugiyono, 2012) menyatakan bahwa analisis data adalah proses mencari dan menyusun secara sistematis data yang diperoleh dari hasil wawancara, catatan lapangan, dan dokumentasi, dengan cara mengorganisasikan data kedalam kategori, menjabarkan ke dalam unit-unit, melakukan sintesa. Menyusun kedalam pola, memilih mana yang penting dan yang akan dipelajari, dan membuat kesimpulan sehingga mudah dipahami oleh diri sendiri maupun orang lain.

(Riyanto, 2007) Uji keabsahan data yang dilakukan dalam penelitian ini adalah dikenal dengan istilah "trianggulasi data" yaitu teknik pemeriksaan keabsahan data yang memanfaatkan sesuatu yang lain. Dengan trianggulasi data peneliti dapat merechek temuannya dengan jalan membandingkan dengan berbagai sumber, metode atau teori yang dapat dilakukan dengan jalan mengajukan berbagai macam variasi pertanyaan, mengecek dengan berbagai sumber data, serta memanfaatkan metode agar pengecekan kepercayaan data dapat dilakukan.

Tahapan penelitian ada tiga dan ditambah dengan tahap terakhir penelitian yaitu penulisan laporan hasil penelitian. Tahap-tahap penelitian tersebut adalah:

1. Tahap sebelum penelitian, beberapa yang perlu disiapkan oleh peneliti, diataranya mengurus perizinan pada pihak jurusan sebagai syarat melakukan observasi awal di SMK Negeri 6 Makassar dan menyusun rancangan penelitian berupa pertanyaan yang akan ditanyakan kepada informan di lapangan.
2. Tahap penelitian, meliputi mengumpulkan bahan-bahan yang berkaitan dengan penerimaan peserta didik.

3. Tahap analisis data, meliputi analisis data baik yang diperoleh melalui wawancara yang mendalam dengan, kepala sekolah dan guru.

4. Tahap penulisan laporan, meliputi: kegiatan penyusunan hasil penelitian dari semua rangkaian kegitan pengumpulan data sampai pemberian makna data.

\section{HASIL DAN PEMBAHASAN}

\section{Analisis penerimaan peserta didik baru}

Secara garis besar hasil penelitian yang telah didapatkan melalui proses wawancara dan dokumentasi menunjukkan bahwa pada tahap analisis penerimaan peserta didik baru, ada beberapa yang menjadi pertimbangan yaitu melihat dari ketersediaan kelas belajar untuk peserta didik dan rasio antara guru dan peserta didik.

Senada dengan hasil penelitian, menurut Kompri (2015) memberi keterangan bahwa, yang termasuk dalam kegiatan analisis penerimaan peserta didik baru adalah merencanakan jumlah siswa yang akan diterima yaitu daya tampung sekolah dan kelas, rasio peserta didik dan guru yang bertujuan membandingkan antara banyaknya peserta didik dan guru dapat seimbang dan menyusun program kegiatan peserta didik, meliputi visi misi dan tujuan sekolah, minat bakat peserta didik, sarana dan prasarana, anggaran yang tersedia dan tenaga kependidikan yang tersedia.

Dalam penentuan daya tampung dalam 1 rombel telah ditentukan secara objektif, dimana daya tampung yang diterima sebanyak 420 dan 12 rombel. Dalam 1 rombel memiliki daya tampung sebanyak 35 peserta didik hal ini sudah ditentukan pada kebijakan pemerintah yaitu Peraturan Menteri Pendidikan Dan Kebudayaan Republik Indonesia Nomor 17 Tahun 2017 Tentang "Penerimaan Peserta Didik Baru Pada Taman Kanak-Kanak, Sekolah Dasar, Sekolah Menengah Pertama, Sekolah Menengah Atas, Sekolah Menengah Kejuruan, Atau Bentuk Lain Yang Sederajat pasal 24" yaitu SMK dalam satu kelas berjumlah paling sedikit 15 (lima belas) peserta didik dan paling banyak 36 (tiga puluh enam) peserta didik. 
Adapun hasil penemuan peneliti secara keseluruhan bahwasanya jumlah peserta didik dalam 1 rombel yaitu terdiri atas 35-36 peserta didik hal ini sama dengan kebijakan pemerintah terkait dengan penentuan rombel di SMK yaitu 35-36 dalam 1 Rombel. Namun peneliti mendapat temuan bahwasanya rasio Guru dan peserta didik sangatlah jauh. Dimana jumlah guru hanya 89 guru dan peserta didik sebanyak 1275 . Dapat kita ketahui dari hasil wawancara, observasi serta Dokumentasi bahwasanya rasio antara guru dan juga peserta didik belum seimbang. Hal ini sudah diperkuat oleh hasil dokumentasi yang berupa SK jam mengajar guru serta data jumlah peserta didik.

\section{Kebijakan penerimaan peserta didik berbasis online}

Berdasarkan hasil penelitian yang telah dihimpun menunjukkan bahwa proses penerimaan peserta didik berbasis online yang dilaksanakan, berpedoman pada Peraturan Pemerintah RI nomor 17 Tahun 2010 "Tentang pengelolaan dan penyelenggaraan pendidikan pasal 82 ayat 1" penerimaan peserta didik pada satuan pendidikan menengah dilakukan secara objektif, transparan dan akuntabel. Dalam peraturan nomor 17 tahun 2010, PPDB Online bertujuan untuk menjamin penerimaan peserta didik baru berjalan secara objektif, transparan, akuntabel, nondiskriminatif dan berkeadilan dalam rangka mendorong peningkatan akses layanan pendidikan.

Selain mengacu dari kebijakan yang berlaku secara nasional dalam prosesnya, adapun pedoman yang dibuat oleh dinas pendidikan provinsi Sulawesi selatan yaitu Keputusan Gubernur Sulawesi Selatan Nomor 1802/VI/Tahun 2018 Tentang Petunjuk Teknis Pelaksanaan Penerimaan Peserta Didik Baru (PPDB) Online Jenjang SMA Negeri, SMK Negeri Dan SLB Negeri Provinsi Sulawesi Selatan Tahun Pelajaran 2018/2019. Pedoman petunjuk teknis inilah yang menjadi pedoman dalam pelaksanaan penerimaan peserta didik baru berbasis online Yang menetapkan beberapa kebijakan operasional dalam pelaksanaannya sebagai langkah teknis kegiatan, mulai dari proses pendaftaran, penentuan kriteria, hingga pengumuman hasil seleksi. Hal tersebut dilakukan untuk mempermudah penjaringan calon peserta didik sesuai dengan yang diharapkan. Senada dengan hasil Penelitian, menurut (Prihatin, 2011) Kebijakan penerimaan peserta didik baru ini dibuat berdasarkan petunjuk-petunjuk yang di berikan oleh Dinas pendidikan kabupaten/kota. Petunjuk demikian harus di pedomani, karena ia memang di buat dalam rangka mendapatkan calon peserta didik sebagaimana yang di inginkan atau di idealkan

Adapun hasil yang peneliti temukan bahwasanya kebijakan sekolah diataranya penentuan jumlah peserta didik yang diterima serta tempat pendaftran bagi calon peserta didik yang ditetapkan di ruangan rapat guru serta anggaran pelakasanan penerimaan peserta didik online berasal dari dana BOS Sekolah.

\section{Sistem penerimaan peserta didik baru}

Sistem pada penerimaan peserta didik baru berbasis online di SMK Negeri 6 makassar memiliki 4 sistem penerimaan, pertama, jalur Prestasi, Jalur Prestasi adalah jalur pendaftaran untuk calon peserta didik baru yang memiliki prestasi dalam lomba akademik dan non akademik yang berdomisili di luar zona terdekat dari Sekolah. Kedua, jalur afirmasi yaitu Jalur Afirmasi adalah jalur pendaftaran untuk calon peserta didik baru yang berasal dari keluarga ekonomi tidak mampu dan berdomisili pada radius zona terdekat dari sekolah. Selanjutnya ada yang dikatakan jalur khusus yang dikatakan jalur khusus yaitu jalur pendaftaran untuk calon peserta didik baru dengan alasan khusus, meliputi perpindahan domisili orang tua/wali atau terjadi bencana alam/sosial yang berdomisili di luar zona radius terdekat dari Sekolah. pada masing-masing jalur ini telah ditentukan kuota masing-masing jalur. Di jalur Prestasi memiliki kuota sebanyak 5\% khusus 5\% afirmasi $20 \%$ sedangkan akademik $70 \%$.

Seperti yang dikemukakan oleh (Prihatin, 2011) yaitu Sistem seleksi ini dapat di golongkan menjadi tiga macam. Pertama, seleksi berdasarkan daftar nilai ujian akhir nasional (UAN), yang kedua berdasarkan penelusuran minat dan kemampuan (PMDK), sedangkan yang ketiga adalah seleksi berdasarkan hasil tes masuk Sistem seleksi dengan penulusuran minat dan kemampuan (PMDK) dilakukan dengan cara 
mengamati secara menyeluruh terhadap peserta didik pada sekolah sebelumnya.

Adapun hasil penelitian yaitu teori mengenai sistem penerimaan peserta didik baru yang sama halnya sistem yang diterapkan di SMK Negeri 6 Makassar yaitu melakukan seleksi dengan melihat hasil nilai ujian akhir nasional (UAN) dimana SMK Negeri 6 Makassar menerapkan sistem jalur Akademik serta afirmasi. Adapun seleksi berdasarkan penelusuran minat dan kemampuan (PMDK) melihat dari prestasi atau kemampuan yang dimiliki oleh calon peserta didik baru dimana jalur ini disebut dengan jalur Prestasi serta sistem seleksi dengan penulusuran minat dan kemampuan (PMDK) dilakukan dengan cara mengamati secara menyeluruh terhadap peserta didik pada sekolah sebelumnya yang dimana jalur khusus melihat sekolah atau tempat tinggal pada calon peserta didik sebelumnya.

\section{Kriteria penerimaan peserta didik baru}

Yang dimaksud dengan kriteria adalah patokan-patokan yang menyatukan bisa atau tidaknya seorang untuk diterima sebagai peserta didik. Ada beberapa persyaratan atau kriteria yang harus diberikan oleh calon peserta didik di setiap jalurnya. Namun kriteria yang diberikan oleh calon peserta didik, melihat dari Keputusan Gubernur Sulawesi Selatan Nomor 1802/VI/Tahun 2018 Tentang Petunjuk Teknis Pelaksanaan Penerimaan Peserta Didik Baru (PPDB) Online Jenjang SMA Negeri, SMK Negeri Dan SLB Negeri Provinsi Sulawesi Selatan Tahun Pelajaran 2018/2019.

Dalam penentuan kriteria persyaratan bagi calon peserta didik ada bermacammacam dilihat dari setiap jalur. Jalur Prestasi yaitu Diutamakan pada prestasi yang diperoleh pada kejuaraan yang diselenggarakan oleh Kementerian Pendidikan dan Kebudayaan, Kementerian Agama, Komite Olahraga Nasional Indonesia (KONI) dan Lembaga atau Organisasi yang memiliki induk organisasi di tingkat Kabupaten/Kota, tingkat Provinsi, dan tingkat Pusat. Hasil Prestasi ditunjukkan dengan sertifikat, piagam penghargaan dan atau medali. Sertifikat dan piagam penghargaan yang diperoleh tercatat pada database Dinas Pendidikan, Kemenag dan KONI. Sedangkan jalur khusus yaitu memiliki kriteria dan persyaratan salah satunya Calon peserta didik baru yang mengikuti perpindahan domisili orang tua/wali karena faktor bencana alam dan factor bencana sosial. Calon peserta didik baru yang merupakan anak dari anggota TNI, POLRI dan ASN yang mengalami perpindahan tugas antar Kabupaten/Kota dan luar Provinsi. Selain jalur prestasi dan khusus adapun persyaratan bagi jalur afirmasi yaitu salah satunya calon peserta didik baru memperoleh Kartu Program Keluarga Harapan dengan cara yang tidak sesuai dengan ketentuan perolehannya, maka akan dikenai sanksi pengeluaran dari Sekolah. selain itu bagi jalur akademik memiliki kriteria dan persyaratan Calon peserta didik baru yang mengikuti Ujian Nasional Berbasis Komputer (UNBK) mendapat tambahan nilai sebanyak $20 \%$ (dua puluh) dari nilai UNBK dan calon peserta didik baru yang mengikuti Ujian Nasional Kertas Pensil (UNKP) tidak diberi tambahan nilai.

Senada dengan hasil penelitian, menurut Imron (2011) yaitu Ada tiga macam kriteria penerimaan perserta didik. Pertama, adalah kriteria acuan patokan (standard criterian referenced), yaitu suatu penerimaan peserta yang didasakan atas patokan. Patokan yang telah ditentukan sebelumnya. Kedua, kriteria acuan norma(norm criterian referenced), yaitu penerimaan calon pserta didik yang di dasarkan atas keseluruhan prestasi calon peserta didik yang mengikuti seleksi. Dan Ketiga, kriteria yang di dasarkan atas daya tampung sekolah, sekolah terlebih dahulu menentukan berapa jumlah daya tampungnya, atau berapa calon peserta didik baru yang akan diterima.

\section{Prosedur penerimaan peserta didik baru.}

Pada dasarnya prosedur penerimaan yang baik adalah prosedur yang sifatnya mudah dan dapat dipahami oleh peminatnya (Wintoko, 2016). Sudah kita ketahui prosedur penerimaan peserta didik sudah berbasis online mulai dari pendaftaran dan verifikasi data calon peserta didik yang mendaftar hingga pendaftaran ulang bagi calon peserta didik yang diterima.

Prosedur penerimaan peserta didik baru online di SMK Negeri 6 Makassar berperdoman pada Petunjuk teknis dari pemerintah Sulawesi selatan yaitu Keputusan Gubernur Sulawesi Selatan Nomor : 1802/VI/Tahun 2018 Tentang Petunjuk Teknis Pelaksanaan Penerimaan Peserta Didik Baru (PPDB) Online Jenjang 
SMA Negeri, SMK Negeri Dan SLB Negeri Provinsi Sulawesi Selatan Tahun Pelajaran 2018/2019. Pada pelaksanan PPDB Online di SMK Negeri 6 Makassar, dimulai dari penempelan pengumuman yang berupa baliho di sekitaran sekolah agar peserta didik dapat dengan jelas pengumuman penerimaan peserta didik baru mulai dari jadwal hingga persyaratn yang telah ditentukan.

Dalam pendaftaran ppdb online, peserta didik haruslah membuka situs PPDB online Provinsi Sulawesi Selatan melaui http://epanrita.sulselprov.go.id untuk melakukan pendaftaran online. Setelah pendaftaran telah selesai, panitia langsung melakukan ferifikasi data peserta didik yang mendaftar. Selanjutnya setelah pelaksanaan pendaftaran adapun tahap pengumuman yaitu Diumumkan serentak, langsung, transparan, dan akuntabel melalui Aplikasi PPDB online pada laman e-Panrita dengan alamat http://epanrita.sulselprov.go.id pada saat pengumuman kelulusan peserta didik, sekolah juga telah menempelkan namanama yang telah lulus di SMK Negeri 6 Makassar berserta dengan pengumuman waktu pelaksanaan pendaftaran ulang bagi peserta didiik yang dinyatakan lulus. (Utami et al., 2018) Website Penerimaan Peserta Didik Baru (PPDB) memberikan kemudahan bagi orang tua dan calon peserta didik baru dalam mengetahui informasi mengenai pelaksanaan seleksi penerimaan peserta didik baru

Senada dengan hasil penelitian, menurut (Imron, 2011) yaitu Prosedur penerimaan peserta didik baru adalah pembentukan panitia penerimaan peserta didik baru, rapat penentuan peserta didik baru, pembuatan, pemasangan atau pengiriman pengumuman, pendaftaran peserta didik baru, seleksi, penentuan peserta didik baru yang diterima, pengumuman peserta didik yang diterima dan registrasi peserta didik yang diterima dan registrasi peserta didik yang diterima.

\section{KESIMPULAN}

Berdasarkan analisis data dan pembahasan hasil penelitian tentang Manajemen Penerimaan Peserta didik baru berbasis Online di SMK Negeri 6 Makassar, maka dapat disimpulkan bahwa:
Pelaksanaan PPDB Online pada tahun ajaran 2018/2019, berpedoman pada Keputusan Gubernur Sulawesi Selatan Nomor 1802/VI/Tahun 2018 Tentang Petunjuk Teknis Pelaksanaan Penerimaan Peserta Didik Baru (PPDB) Online Jenjang SMA Negeri, SMK Negeri Dan SLB Negeri Provinsi Sulawesi Selatan Tahun Pelajaran 2018/2019 serta sistem penerimaan yang diterapkan di SMK Negeri 6 Makassar yaitu ada 4 diantaranya, Jalur Afirmasi, Khusus, Prestasi serta Akademik. Penyeleksian pada PPDB Online saat ini telah terhubung langsung dengan database Dinas sosial dan Dinas Pendidkan, Kemenag dan KONI. Adapun Prosedur penerimaan peserta didik baru yaitu PPDB online saat ini lebih transparansi dan memudahan bagi peserta didik serta panitia dalam menverifikasi data yang sebenarnya, serta pertanggung jawaban panitia lebih mudah dikarenakan semua data telah menggunakan sistem.

\section{DAFTAR RUJUKAN}

Gunawan, I. (2017). Manajemen Pendidikan. Bandung: Alfabeta.

Imron, A. (2011). Manajemen Peserta Didik Berbasis Sekolah. Jakarta: Bumi Aksara.

Kompri. (2015). Manajemen Pendidikan. Bandung: Alfabeta.

Latri, W. (2017). Evaluasi Program Penerimaan Peserta Didik Baru ( Ppdb ) Dengan Sistem Real Time Online ( Rto ) Di Sma Negeri 2 Bantul. Jurnal Hanta Widaya, 5(9), 22-27.

Moleong, J. (2014). Lexy, Metodologi Penelitian kualitatif, Penerbit PT. Remaja Rosdakarya Bandung.

Mulyasa, E. (2004). Manajemen Berbasis Sekolah, Konsep, Strategi dan Implementasi. Bandung: Rosdakarya.

Mutiarin, D., \& Wijaya, J. H. (2017). Evaluasi Penerapan Siap -Ppdb Online Dalam Meningkatkan Mutu Online Siap-Ppdb Evaluation Toward Educational Services Quality. Jurnal Penelitian Pers Dan Komunikasi Pembangunan. Jurnal Penelitian Pers Dan Komunikasi Pembangunan, 21(2), 83-99.

Prihatin, Ek. (2011). Teori Administrasi Pendidikan. Bandung: Alfabeta.

Purwanti, D., Irawati, I., Adiwisastra, J., \& Bekti, H. (2019). Implementasi 
Kebijakan Penerimaan Peserta Didik Baru Berdasarkan Sistem Zonasi di Kota Bandung. Jurnal Governasi, 5(1), $12-23$.

Riyanto, Y. (2007). Metodologi Penelitian Pendidikan Kualitatif dan Kuantitatif. Surabaya: UNESA Universiy Press.

Sari, A. U. (2016). Efektivitas Penerimaan Peserta Didik Baru (Ppdb) Melalui Sistem Penerimaan Peserta Didik Online. Profesionalisme Pendidik Untuk Membangun Anak Bangsa, 1, 1-11.

Sholihin, M., \& Mujilahwati, S. (2014). Sistem Penerimaan Peserta Didik Baru Berbasis Web (Online ) Di SMK Muhammadiyah 7 Kedungpring Lamongan. 6(1), 557-560.

Sugiyono. (2012). Metode Penelitian Kuantitatif Kualitatifdan R\&D. Bandung: Alfabeta.

Sularto, Wahyudi, \& Sukmawati. (2018). The Admission of New Students Based on Online System at SMAN 2 Singkawang. Jurnal of Education, Teaching and Learning, 3(2), 336-341.

Syafi, A., Eka, Z., Sari, M., \& Arif, M. (2018). Pengembangan Sistem Informasi Penerimaan Siswa Baru Berbasis WEB Di SMA 1 Annuqayah Sumenep. Jurnal IImiah Edutic, 4(2), 53-62.

Utami, L. A., Kom, M., Studi, P., Informasi, S., Ishaq, A., Kom, M., ... Informatika, M. (2018). Analisa Pengaruh Kualitas Website PPDB Terhadap Kepuasan Pengguna. Jurnal Penelitian Teknik Informatika, 3(3), 31-37.

Wintoko, A. (2016). Implementasi Pelayanan Publik Program Penerimaan Peserta Didik Baru Melalui Sistem Online (Studi Di Sman 1 Banyuwangi Dan Sman 1 Singojuruh Kabupaten Banyuwangi). Jurnal Administrasi Publik, 4(4). 